p-ISSN: $2338-4794$

e-ISSN: $2579-7476$

Vol.8. No. 3 September-Desember 2020

\title{
PENGARUH KUALITAS LAYANAN DAN CITRA MEREK TERHADAP KEPUASAN KONSUMEN HOTEL GRAND CANDI SEMARANG
}

\author{
Iwan Kurniawan Subagja ${ }^{1)}$ \\ 1) Dosen Program Studi Manajemen FE UNKRIS \\ Alamat: Kampus UNKRIS, Jatiwaringin Jakarta Timur \\ Email: iwankurniawan@unkris.ac.id \\ Azis Hakim 2) \\ 2) Dosen Program Studi Ilmu Administrasi UNKRIS \\ Email: dr_azishakim@yahoo.com
}

\begin{abstract}
This study aims to determine the effect of service quality and brand image on customer satisfaction. The research was conducted at Hotel Grand Candi Semarang. The sampling technique used simple random sampling and data analysis used multiple linear regression analysis. The results showed that service quality and brand image had a positive and significant effect on customer satisfaction at Hotel Grand Candi Semarang.
\end{abstract}

Keywords: Service quality, brand image, and customer satisfaction.

\section{PENDAHULUAN}

Pada era globalisasi saat ini, perkembangan persaingan bisnis di Indonesia sangat cepat, salah satunya perkembangan bisnis perhotelan dan pariwisata. Hal yang merupakan bagian penting dari pariwisata adalah hotel.
Hotel merupakan sarana penting dalam menunjang kesuksesan pariwisata, karena pembangunan hotel berkembang seiring dengan pembangunan industri pariwisata di suatu daerah.

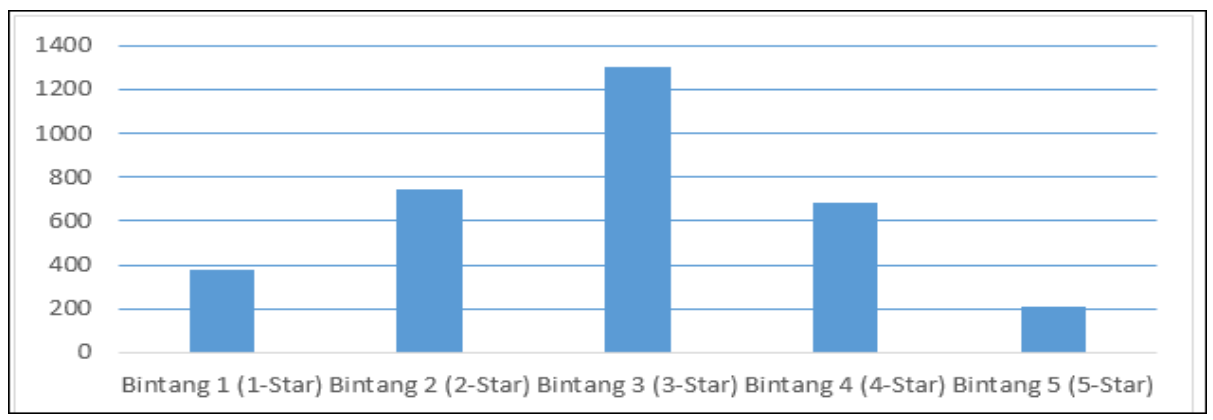

Gambar 1. Jumlah Hotel di Indonesia Tahun 2018

Berdasarkan data dari Badan Pusat Statistik (BPS), kunjungan wisatawan ke Indonesia pada Februari 2019 naik 6,12\% dibanding jumlah kunjungan pada
Februari 2018, yaitu dari 1,2 juta menjadi 1,27 juta kunjungan. Hal ini dimanfaatkan oleh investor untuk berlomba-lomba membangun hotel 
dengan menawarkan berbagai fasilitas. Berdasarkan data dari BPS pada tahun 2018, jumlah hotel berbintang yang terbanyak adalah hotel bintang tiga, yaitu 1.302 hotel $(39,29 \%)$, diikuti hotel bintang dua sebanyak 745 hotel
$(22,48 \%)$. Urutan ke tiga hotel bintang empat sebanyak 682 hotel $(20,58 \%)$, diikuti urutan ke empat hotel bintang satu sebanyak 375 hotel $(11,32 \%)$ dan urutan ke lima hotel bintang lima sebanyak 210 $(6,34 \%)$.

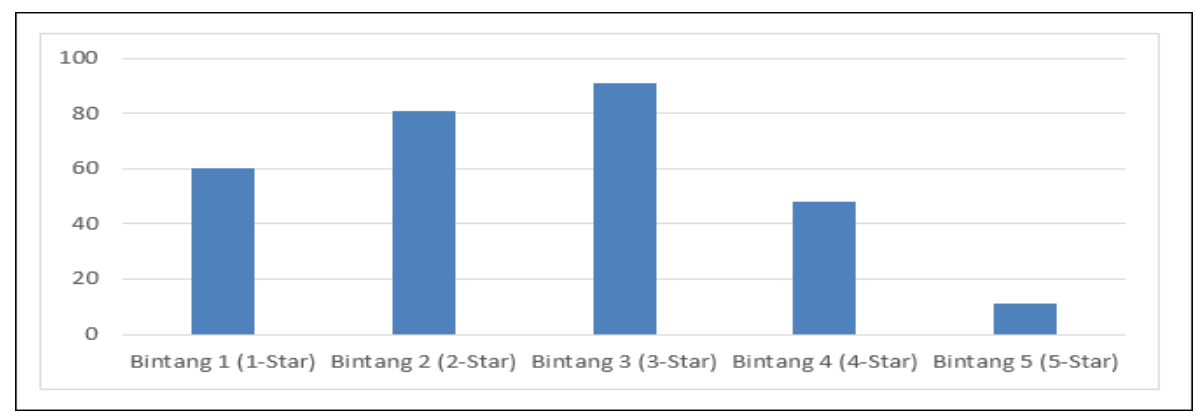

Gambar 2. Jumlah Hotel di Jawa Tengah Tahun 2018

Hotel saat ini bukan saja sebagai tempat menginap, namun hotel sudah menjadi media untuk menyalurkan gaya hidup masyarakat yang semakin modern. Segala fasilitas yang ditawarkan hotel saat ini sangat beragam, seperti menawarkan fasilitas dari aspek kesehatan, kuliner, media pertemuan bisnis, seminar, tempat resepsi pernikahan dan lain sebagainya. Hotel dijadikan sebagai tempat melakukan berbagai kegiatan karena memiliki saran dan prasarana yang lengkap untuk menunjang berbagai kegiatan yan dilakukan oleh para tamu.

Persaingan hotel di Indonesia saat ini sangat ketat, khususnya di Kota Semarang, Jawa Tengah. Berdasarkan data dari BPS tahun 2018, jumlah hotel berbintang yang terbanyak adalah hotel bintang tiga, yaitu 91 hotel $(31,27 \%)$, diikuti hotel bintang dua sebanyak 81 hotel $(27,84 \%)$. Urutan ke tiga hotel bintang satu sebanyak 60 hotel $(20,62 \%)$, diikuti urutan ke empat hotel bintang empat sebanyak 48 hotel $(16,49 \%)$ dan urutan ke lima hotel bintang lima sebanyak 11 hotel $(3,78 \%)$.

Salah satu hotel yang berada di Jawa Tengah adalah Hotel Grand Candi.
Hotel Grand Candi merupakan hotel bintang lima yang menerapkan konsep bangunan ramah lingkungan di Jawa Tengah. Banyaknya hotel di Jawa Tengah, perusahaan perlu memikat konsumen agar tetap survive di tengah persaingan yang ketat. Fenomena ini menyebabkan perusahaan jasa memikat konsumennya dengan peningkatan layanan, kemudahan pemesanan, kenyamanan, ketepatan waktu dan lain sebagainya, sehingga terciptanya citra yang baik dan timbulnya kepuasan konsumen. Banyak faktor yang mempengaruhi kepuasan konsumen di antaranya adalah kualitas layanan dan citra merek. Kualitas layanan merupakan unsur penentu dalam perusahaan untuk mempertahankan konsumen. Kualitas layanan sebagai usaha untuk mewujudkan kenyamanan terhadap konsumen agar konsumen merasa mempunyai nilai yang lebih dari yang diharapkan, sehingga terbentuk pula citra yang baik di mata konsumen (Tjiptono, 2016).

Berdasarkan hasil penelitian Agyapong (2011) membuktikan bahwa kualitas layanan memberikan pengaruh terhadap kepuasan konsumen 
telekomunikasi Vodafone. Bharwana, et al (2013) dalam penelitian membuktikan variabel kualitas layanan memberikan pengaruh terhadap kepuasan konsumen pada perguruan tinggi swasta di Pakistan. Saleem dan Raja (2014) dalam penelitian mampu membuktikan kualitas layanan memberikan pengaruh terhadap kepuasan konsumen pada Industri Hotel di Pakistan. Rahayu (2015) dalam penelitian membuktikan bahwa kualitas layanan tidak memberikan pengaruh terhadap kepuasan konsumen pada Industri Maskapai Penerbangan di Jakarta. Begitu juga dengan penelitian yang dilakukan oleh Putri dan Subagja, (2017); Setiawan dan Sayuti (2017); Dharmawan dan Kristianingsih (2018) membuktikan bahwa kualitas layanan memberikan pengaruh terhadap kepuasan konsumen.

Citra merek menggambarkan sifat ekstrinsik dari suatu produk atau jasa termasuk cara di mana merek berusaha memenuhi kebutuhan psikologis atau sosial pelanggan (Kotler dan Keller, 2016. Citra merek merupakan pemahaman konsumen mengenai merek secara keseluruhan. Dari pengertian citra merek tersebut dapat disimpulkan bahwa citra merek merupakan persepsi dan kepercayaan yang dimiliki oleh konsumen terhadap merek tertentu. Berdasarkan hasil penelitian Susanto dan Subagja (2019); Naimi (2014); Neupane (2015); Mutmainnah (2017); Setiawan, dan Sayuti (2017); Ginantra dan Darma (2017) menunjukkan bahwa variabel citra merek memberikan pengaruh terhadap kepuasan.

\section{LANDASAN TEORI}

\section{Kepuasan Konsumen}

Kepuasan konsumen merupakan faktor utama bagi perusahaan untuk memperhatikan bisnis dan memenangkan pesaing di antara perusahaan sejenis, meskipun tidak mudah untuk mewujudkan kepuasan konsumen secara menyeluruh, namun perusahaan harus meminimalkan ketidakpuasan pelanggan dengan memberikan sistem layanan dengan sebaik mungkin. Kepuasan konsumen adalah respon emosional terhadap pengalaman-pengalaman berkaitan dengan produk atau jasa tertentu, serta pasar secara keseluruhan (Westbrook dan Relly dalam Tjiptono, 2014). Kepuasan konsumen adalah perasaan senang atau kecewa seseorang yang muncul setelah membandingkan antara kinerja atau hasil yang diharapkannya (Kotler dan Keller, 2012). Berdasarkan pengertian-pengertian tersebut di atas dapat disimpulkan bahwa kepuasan konsumen adalah tingkat perasaan yang dirasakan seseorang atas produk atau jasa yang diterima dengan membandingkan kinerja atas produk atau jasa yang diterima dengan harapan yang dimiliki. Indikator kepuasan konsumen terdiri atas kesesuaian harapan, kesediaan merekomendasikan, dan minat berkunjung kembali.

\section{Kualitas Layanan}

Kualitas pelayanan adalah tingkat keunggulan yang diharapkan dan pengendalian atas tingkat keunggulan tersebut untuk memenuhi keinginan pelanggan (Tjiptono, 2016), sedangkan menurut Lupiyoadi (2014) kualitas layanan adalah setiap tindakan atau kegiatan yang ditawarkan oleh satu pihak kepada pihak lain pada dasarnya tidak berwujud dan tidak mengakibatkan perpindahan kepemilikan apapun. Dari pengertian kualitas layanan tersebut dapat disimpulkan bahwa kualitas layanan merupakan kegiatan yang dilakukan pihak lain kepada konsumen untuk memenuhi keinginan konsumen.

Perkembangan perusahaan menciptakan persaingan yang ketat. Salah satu strategi yang dipakai perusahaan untuk bisa memenangkan persaingan 
adalah dengan kualitas layanan yang baik. Pelanggan tertarik membeli sebuah produk atau jasa karena kualitas layanan yang baik.

Terdapat faktor yang mempengaruhi sebuah layanan adalah expected service (layanan yang diharapkan) dan perceived service (layanan yang diterima). Jika layanan yang diterima sesuai bahkan dapat memenuhi apa yang diharapkan, maka jasa dikatakan baik atau positif. Jika perceived service melebihi expected service, maka kualitas layanan dipersepsikan sebagai kualitas ideal. Sebaliknya apabila perceived service lebih buruk dibandingkan expected service, maka kualitas layanan dipersepsikan negatif atau buruk (Parasuraman dalam Tjiptono, 2016). Oleh sebab itu, baik tidaknya kualitas layanan tergantung pada kemampuan perusahaan dan sifatnya memenuhi harapan pelanggan secara konsisten. Indikator kualitas layanan terdiri dari lima unsur penting yaitu, bukti fisik, jaminan, empati, ketanggapan, dan kehandalan. Untuk mewujudkan layanan yang berkualitas, perusahaan harus mampu memenuhi layanan yang diharapkan pelanggan.

\section{Citra Merek}

Menurut Kotler dan Amstrong (2016), citra merek adalah sekumpulan keyakinan terhadap suatu merek. Citra merek adalah sekumpulan keyakinan terhadap suatu merek (Kotler dan Amstrong, 2013). Citra merek adalah sekumpulan persepsi dan kepercayaan yang dimiliki oleh konsumen terhadap brand yang direfleksikan melalui asosiasi-asosiasi yang ada dalam ingatan konsumen (Kotler dan Keller, 2012). Citra merek merupakan pemahan konsumen mengenai merek secara keseluruhan. Kepercayaan konsumen terhadap suatu merek tertentu dan bagaimana konsumen memandang suatu merek. Citra merek yang positif akan membuat konsumen menyukai suatu produk dengan merek yang bersangkutan di kemudian hari, sedangkan bagi produsen citra merek yang baik akan menghambat kegiatan pemasaran pesaing. Indikator citra merek terdiri atas identitas merek, personalitas merek, asosiasi merek, sikap dan perilaku merek, manfaat dan keunggulan merek.

\section{METODE PENELITIAN}

\section{Instrumen Penelitian}

Instrumen penelitian adalah suatu alat yang digunakan untuk mengukur fenomena alam maupun sosial yang diamati dan secara spesifik semua fenomena ini disebut dengan variabel penelitian (Sugiyono, 2008). Instrumen atau alat ukur dalam penelitian ini berupa angket yang berisi butir-butir pertanyaan untuk diberi tanggapan oleh para subjek penelitian. Penyusunan angket tersebut didasarkan pada konstruksi teoritik yang telah disusun sebelumnya. Kemudian atas dasar teoritik tersebut dikembangkan dalam indikator-indikator dan selanjutnya dikembangkan dalam butir-butir pertanyaan. Sistem pengolahan data yang dilakukan pada penelitian ini adalah dengan menggunakan Skala Likert, yaitu skala yang digunakan untuk mengukur sikap, pendapat dan persepsi seseorang atau sekelompok orang tentang fenomena sosial (Sugiyono, 2012).

\section{Populasi dan Sampel}

Populasi adalah wilayah generalisasi yang terdiri atas objek dan subjek penelitian yang mempunyai kualitas dan karakteristik tertentu yang ditetapkan oleh peneliti untuk dipelajari dan kemudian ditarik kesimpulannya (Sugiyono, 2008). Populasi dalam penelitian ini adalah konsumen Hotel 
Grand Candi yang berjumlah 1.062 orang.

Sampel adalah sebagian atau wakil dari populasi yang memiliki sifat dan karakter yang sama serta memenuhi populasi yang diselidiki (Sugiyono, 2008). Penelitian ini menggunakan ukuran sampel dengan rumus Solvin (Husein, 2011) Berdasarkan Slovin, diperoleh sampel sebanyak 91,39 responden, dibulatkan menjadi 100 responden.

\section{Metode Pengumpulan Data}

Sumber data dalam penelitian ini adalah data primer. Data primer adalah sumber data yang langsung memberikan data kepada pengumpul data (Sugiyono, 2014). Dalam penelitian ini, data primer diperoleh dari penyebaran kuesioner kepada konsumen yang pernah menginap di Hotel Grand Candi. Kuesioner merupakan metode pengumpulan data dengan mengajukan pertanyaan tertulis yang disusun secara sistematis kepada responden. Teknik ini digunakan untuk memperoleh data primer yang diperlukan sebagai dasar analisis. Penelitian dilakukan di Hotel Grand Candi yang berlokasi di Jalan Sisingamangaraja No.16, Kaliwiru, Kec. Candisari, Kota Semarang, Jawa Tengah 50232.
Metode analisis yang digunakan adalah analisis regresi linier linear sederhana dan berganda. Untuk menganalisis pengaruh kualitas layanan terhadap kepuasan konsumen dan menganalisis pengaruh citra merek terhadap kepuasan konsumen digunakan analisis regresi linerar sederhana. Analisis regresi linerar berganda digunakan untuk menganalisis pengaruh kualitas layanan dan citra merek terhadap kepuasan konsumen. Persamaan analisis regresi linear sederhana dan berganda adalah sebagai berikut:

$Y=a_{1}+b_{1} X_{1} \ldots \ldots \ldots \ldots \ldots$
$Y=a_{2}+b_{2} X_{2} \ldots \ldots \ldots \ldots \ldots$
$Y=a_{3}+b_{1} X_{1}+b_{2} X_{2} \ldots \ldots$

di mana;

$\mathrm{Y}=$ Kepuasan konsumen

$\mathrm{X}_{1}=$ Kualitas layanan

$\mathrm{X}_{2}=$ Citra merek

$\mathrm{a}_{\mathrm{i}}=$ konstanta $(\mathrm{i}=1,2,3)$

$b_{i}=$ Koefisien regresi $(i=1,2)$

\section{HASIL PENELITIAN DAN PEMBAHASAN}

Hasil Penelitian

Analisis regresi linier sederhana

\section{Teknik Analisis Data}

Tabel-1: Pengaruh Kualitas Layanan terhadap Kepuasan Konsumen

\begin{tabular}{lcccc}
\hline \multirow{2}{*}{ Variabel } & \multicolumn{4}{c}{ Parameter } \\
\cline { 2 - 5 } & Konstanta & Koef. Regresi & Sig. & $\boldsymbol{\alpha}$ \\
\hline Kualitas layanan & 10,473 & 0,372 & 0.000 & 0.05 \\
\hline $\mathrm{R}^{2}=0,681$ & & & \\
\hline Sumber: data diolah 2020
\end{tabular}

$$
\mathrm{Y}=10,473+0,372 \mathrm{X}_{1}
$$

Nilai koefisien determinasi $\left(\mathrm{R}^{2}\right)$ sebesar 0.681 artinya kontribusi kualitas layanan kepada kepuasan konsumen Hotel Grand Candi sebesar 68,1\% sedangkan sisanya sebesar $31,9 \%$, disumbangkan variabel lain, seperti citra merek. Kualitas layanan berpengaruh positif dan signifikan terhadap kepuasan 
konsumen Hotel Grand Candi. Nilai koefisien regresi kualitas layanan bertanda positif dapat diartikan bahwa setiap peningkatan kualitas layanan akan meningkatkan kepuasan konsumen Hotel Grand Candi, atau sebaliknya penurunan kualitas layanan akan menurunkan kepuasan konsumen Hotel Grand Candi.

Tabel-2: Pengaruh Citra merek terhadap Kepuasan Konsumen

\begin{tabular}{lcccc}
\hline \multirow{2}{*}{ Variabel } & \multicolumn{4}{c}{ Parameter } \\
\cline { 2 - 5 } & Konstanta & Koef. Regresi & Sig. & $\boldsymbol{\alpha}$ \\
\hline Citra merek & 11,309 & 0,433 & 0.001 & 0.05 \\
\hline $\mathrm{R}^{2}=0,653$ & & & & \\
\hline Sumber: data diolah 2020 & &
\end{tabular}

$$
\mathrm{Y}=11,309+0,433 \mathrm{X}_{2}
$$

Nilai koefisien determinasi $\left(\mathrm{R}^{2}\right)$ sebesar 0.653 artinya kontribusi citra merek kepada kepuasan konsumen Hotel Grand Candi sebesar $65.3 \%$ sedangkan sisanya sebesar $34.7 \%$ disumbangkan variabel lain, seperti kualitas layanan. Citra merek berpengaruh positif dan signifikan terhadap kepuasan konsumen
Hotel Grand Candi. Nilai koefisien regresi citra merek bertanda positif dapat diartikan bahwa setiap peningkatan citra merek akan meningkatkan kepuasan konsumen Hotel Grand Candi, atau sebaliknya penurunan citra merek akan menurunkan kepuasan konsumen Hotel Grand Candi.

\begin{tabular}{|c|c|c|c|c|}
\hline \multirow{2}{*}{ Variabel } & \multicolumn{4}{|c|}{ Parameter } \\
\hline & Konstanta & Koef. Regresi & Sig. & $\mathbf{A}$ \\
\hline Kualitas layanan & \multirow{2}{*}{$-1,761$} & 0,360 & 0,000 & 0.05 \\
\hline Citra merek & & 0,377 & 0,001 & 0.05 \\
\hline F-hitung $=70,133$ & & & 0,000 & 0.05 \\
\hline \multicolumn{5}{|l|}{$\mathrm{R}^{2}=0,591$} \\
\hline Sumber: data diolal & 2020 & & & \\
\hline
\end{tabular}

Uji $\quad \mathrm{F}$ digunakan untuk menunjukkan apakah terdapat pengaruh secara bersama-sama (simultan) variabel bebas dengan variabel terikat. Apabila $\mathrm{F}$ hitung > F tabel dan signifikansi lebih kecil dari $0,05(\mathrm{sig}<0,05)$ dapat disimpulkan bahwa variabel bebas secara simultan berpengaruh signifikan terhadap variabel terikat. Nilai F-hitung sebesar 70,133 dengan derajat kebebasan (df) dan $\alpha=5 \%$, df $1=3-1=2 ; \mathrm{df} 2=100-2-1=97$, sehingga F-tabel sebesar 3,09. Nilai F- hitung $=70,133>$ F-tabel $=3,09$ dan signifikansi pada $\alpha=0,005$, artinya kualitas layanan dan citra merek secara bersama-sama berpengaruh signifikan terhadap kepuasan konsumen Hotel Grand Candi. Koefisien determinasi $\left(\mathrm{R}^{2}\right)$ sebesar 0,591, artinya kontribusi kualitas layanan dan citra merek kepada kepuasan pelanggan sebesar $59,1 \%$, sedangkan sisanya sebesar $40,9 \%$ disumbankan variabel lain yang tidak diteliti. 
Kualitas layanan dan citra merek berpengaruh positif dan signifikan terhadap kepuasan konsumen Hotel Grand Candi. Nilai koefisien regresi kualitas layanan bertanda positif, dapat diartikan bahwa setiap peningkatan kualitas layanan akan meningkatkan kepuasan konsumen Hotel Grand Candi dengan asumsi citra merek tidak berubah, atau sebaliknya. Nilai koefisien regresi citra merek bertanda positif dapat diartikan bahwa setiap peningkatan citra merek akan meningkatkan kepuasan konsumen Hotel Grand Candi dengan asumsi kualitas layanan tidak berubah, atau sebaliknya.

\section{Pembahasan}

\section{Kualitas layanan}

Bukti fisik merupakan kemampuan menunjukkan eksistensinya terhadap pihak eksternal, seperti gedung menarik secara visual, kamar hotel cukup luas, interior dan eksterior menarik serta penampilan fisik karyawan baik. Empati merupakan perhatian yang diberikan karyawan kepada konsumen seperti ramah terhadap konsumen, dan menghargai setiap konsumen yang menginap di Hotel Grand Candi. Ketanggapan merupakan sikap tanggap yang dimiliki karyawan kepada konsumen seperti cepat membantu dalam memberikan informasi, memperhatikan keluhan konsumen serta mudah dihubungi apabila dibutuhkan. Kehandalan merupakan kemampuan karyawan melakukan pekerjaannya dengan tepat dan tanpa kesalahan seperti memberikan pelayanan yang cepat, akurat dan teliti, menjaga sikap dan memberikan informasi kepada konsumen dengan jelas. Jaminan merupakan kemampuan karyawan untuk meyakinkan konsumen seperti memberikan rasa aman dan nyaman, serta memberikan jaminan privasi kepada konsumen selama berada di Hotel Grand Candi. Penilaian konsumen terhadap kualitas layanan dapat ditunjukkan secara deskriptif bahwa konsumen cenderung setuju bukti fisik, empati, ketanggapan, kehandalan dan jaminan dipersepsikan membentuk kualitas layanan. Hal utama pembentukan kualitas layanan adalah jaminan, terutama persepsi responden yang menyatakan bahwa Hotel Grand Candi memberikan jaminan privasi konsumen selama berada di hotel tersebut.

\section{Citra Merek}

Kekuatan asosiasi merek merupakan kekuatan yang dimiliki Hotel Grand Candi untuk membentuk citra merek pada konsumen seperti jenis makanan dan minuman yang beragam di hotel, jenis kamar yang beragam dan fasilitas yang lengkap. Keunggulan asosiasi merek merupakan keunggulan yang membuat konsumen dapat merasakan manfaat yang diberikan dari Hotel Grand Candi seperti hotel selalu konsisten antara janji yang dibuat dalam iklan dengan kenyataan pada saat di hotel serta Hotel Grand Candi yang merupakan hotel yang memiliki konsep bangunan ramah lingkungan. Keunikan asosiasi merek merupakan ciri khas yang menarik konsumen seperti desain logo Hotel Grand Candi yang digunakan berbeda dengan pesaing sejenisnya dan muda diingat. Penilaian konsumen terhadap citra merek dapat ditunjukkan secara deskriptif bahwa konsumen cenderung setuju kekuatan, keunggulan dan keunikan asosiasi merek dipersepsikan membentuk citra merek. Hal utama pembentukan citra merek adalah keunggulan asosiasi merek, terutama persepsi responden yang menyatakan bahwa Hotel Grand Candi selalu konsisten antara janji yang dibuat dalam iklan dengan kenyataan pada saat di 
hotel, di samping itu Hotel Grand Candi merupakan hotel yang memiliki konsep bangunan ramah lingkungan yang dipersepsikan dapat menciptakan hal positif terhadap hotel tersebut.

\section{Kepuasan konsumen}

Kesesuaian harapan merupakan kesesuaian yang diharapkan konsumen ketika menginap di Hotel Grand Candi, seperti pelayanan dan sikap yang diberikan karyawan sesuai dengan harapan dan fasilitas hotel sesuai dengan haapan konsumen. Minat berkunjung kembali merupakan kesediaan konsumen untuk berkunjung kembali ke Hotel Grand Candi karena pelayanan yang diberikan oleh karyawan memuaskan. Kesediaan merekomendasikan merupakan kesediaan konsumen merekomendasikan Hotel Grand Candi kepada pihak lain karena pelayanan yang memuaskan difasilitasi dengan penunjang yang memadai. Penilaian konsumen terhadap kepuasan konsumen dapat ditunjukkan secara deskriptif bahwa konsumen cenderung setuju kesesuaian harapan, minat berkunjung kembali dan kesediaan merekomendasikan. Hal utama pembentuk kepuasan konsumen adalah harga yang ditawarkan sesuai dengan apa yang didapatkan pada saat di Hotel Grand Candi.

\section{Pengaruh kualitas layanan terhadap kepuasan konsumen}

Salah satu upaya hotel untuk dapat bertahan dalam persaingan, hotel harus memberikan layanan yang sesuai dengan yang diharapkan dan tetap konsisten. Jika kualitas layanan yang diterima konsumen sesuai dengan harapan, maka konsumen akan merasa puas. Kualitas layanan mengutamakan memberikan jaminan privasi konsumen selama berada di hotel tersebut. Hasil penelitian ini sejalan oleh penelitian yang dilakukan Kristianingsih (2018); Susanto dan Subagja (2019);
Saleem dan Raja (2014) menunjukkan bahwa kualitas layanan dan fasilitas terhadap kepuasan konsumen.

\section{Pengaruh citra merek terhadap kepuasan konsumen}

Salah satu upaya hotel untuk membangun citra yang positif dan baik kepada konsumen adalah dengan membentuk kekuatan, keunggulan dan keunikan yang dimiliki hotel. Hal tersebut dapat menjadi penghubung antara merek dengan konsumen. Apabila konsumen sudah percaya akan manfaat yang dirasakan ketika menginap di hotel akan menciptakan sikap positif terhadap hotel, sehingga tercipta kepuasan konsumen. Hasil penelitian ini sejalan oleh oleh penelitian yang dilakukan Puteri dan Subagja (2017); Naimi (2014); Mutmainnah (2017) yang menguji hubungan sebab-akibat antara kualitas layanan dengan citra perusahaan terhadap kepuasan dan loyalitas nasabah, bahwa citra merek memiliki pengaruh terhadap kepuasan konsumen.

\section{Pengaruh kualitas layanan dan citra merek terhadap kepuasan konsumen}

Hasil penelitian mengenai peran kualitas layanan dan citra merek terhadap kepuasan konsumen pada Hotel Grand Candi telah teruji bahwa kualitas layanan dan citra merek dapat meningkatkan kepuasan konsumen. Dari hasil penelitian menunjukkan bahwa kualitas layanan dan citra merek dapat dipilih untuk upaya meningkatkan kepuasan konsumen. Namun, citra merek lebih mampu meningkatkan kepuasan konsumen pada Hotel Grand Candi yang diarahkan pada keunggulan asosiasi merek yang merupakan bagian dari citra merek untuk meningkatkan kepuasan konsumen.

\section{KESIMPULAN DAN SARAN}

\section{Kesimpulan}


Berdasarkan dari hasil penelitian dapat disimpulkan beberapa hal, antara lain: 1). Bukti fisik, empati, ketanggapan, kehandalan dan jaminan dipersepsikan membentuk kualitas layanan. Kontribusi terbesar kepada kualitas layanan adalah jaminan, terutama persepsi responden yang menyatakan bahwa Hotel Grand Candi memberikan jaminan privasi konsumen selama berada di hotel tersebut. 2). Kekuatan, keunggulan dan keunikan asosiasi merek dipersepsikan membentuk citra merek. Kontribusi terbesar kepada citra merek adalah keunggulan asosiasi merek, terutama persepsi responden yang menyatakan bahwa Hotel Grand Candi selalu konsisten antara janji yang dibuat dalam iklan dengan kenyataan pada saat di hotel, di samping itu Hotel Grand Candi merupakan hotel yang memiliki konsep bangunan ramah lingkungan yang dipersepsikan dapat menciptakan hal positif terhadap hotel tersebut. 3). Kesesuaian harapan, minat berkunjung kembali dan kesediaan merekomendasikan. Kontribusi terbesar kepada kepuasan konsumen adalah harga yang ditawarkan sesuai dengan apa yang didapatkan pada saat di hotel.

\section{Saran}

Berdasarkan dari hasil penelitian, pembahasan dan kesimpulan yang diperoleh, maka saran yang dapat diberikan sebagai berikut: 1). Berdasarkan hasil penelitian, variabel kualitas layanan pada indikator kehandalan (reliability) mendapat nilai terendah. Oleh karena itu, Hotel Grand Candi disarankan untuk meningkatkan pelayanan dengan cara melakukan pelatihan keterampilan, sehingga dapat melakukan pelayanan yang baik terhadap semua konsumen tanpa melakukan kesalahan apapun. 2). Berdasarkan hasil penelitian, variabel citra merek pada indikator kekuatan asosiasi merek (strength of brand association) mendapat nilai terendah. Oleh karena itu, Hotel Grand Candi disarankan untuk memperbaiki atau meningkatkan fasilitas yang ada di hotel, dan memperbanyak variasi jenis makanan dan minuman sesuai dengan selera konsumen. 3). Berdasarkan hasil penelitian, variabel kepuasan konsumen pada indikator kesediaan merekomendasikan mendapat nilai terendah. Oleh karena itu, Hotel Grand Candi disarankan untuk meningkatkan layanan dan citra yang baik kepada konsumen, sehingga konsumen kemungkinan bersedia merekomendasikan Hotel Grand Candi kepada orang lain. 4). Penelitian ini dapat dijadikan acuan dan penambahan wawasan bagi peneliti. Bagi peneliti selanjutnya akan lebih baik jika ditambah variabel seperti loyalitas konsumen, kualitas produk, promosi, harga, kepercayaan dan fasilitas agar hasil penelitian dapat lebih menggambarkan mengenai objek yang akan diteliti.

\section{DAFTAR PUSTAKA}

Agyapong., G. K. Q. 2011. The Effect of Service Quality on Customer Satisfaction in the Utility Industry A Case of Vodafone (Ghana). International Journal of Business and Management. Vol. 6, No. 5, May 2011, 203-210

Al Bataafi, Wisnu. 2005. House Keeping Department, Floor and Public Area. Bandung: Alfabeta

Alma, Buchari. 2011. Manajemen Pemasaran dan Pemasaran Jasa. Bandung: Penerbit Alfabeta

Ardianto, Elvinari, et al. 2007. Komunikasi Massa: Suatu

Pengantar. Edisi Revisi. Bandung: Simbiosa

Dharmawan, Kristianingsih. 2018. Pengaruh Kualitas Pelayanan dan Fasilitas Terhadap Kepuasaan 
Konsumen di Hotel Pelangi Malang. Jurnal Aplikasi Bisnis. Vol. 4, No. 2, Desember 2018

F. Tombokan, Lotje Kawet, Yantje Uhing. 2015. Pengaruh Kualitas Pelayanan, Citra Merek Terhadap Kepuasan Konsumen Pengguna Taplus BNI Kantor Cabang Utama Manado. Jurnal EMBA. Vol. 3, No. 3, September 2015, 552-561

Ginantra, Komang Gede., Lestari, Ni Putu Nina Eka., Gorda, Eddy Supriyadinata dan Darma, Gede Sri. 2017. Effect of Promotion, Product Quality, Brand Image and Price on Customer Satisfaction and Brand Switching Decision. International Journal of Management and Economics. Vol. 3, No. 12, December 2017, 15141523

Kotler, Philip \& Armstrong, Gary. 2014. Principle of Marketing. $15^{\text {th }}$ Edition. New Jersey: Printince Hall. 2016. Service Quality \& Satisfaction. Yogyakarta. Andi

Lovelock, Christopher, Jochen Wirtz \& Jacky Mussry. 2011. Pemasaran Jasa. Edisi 7. Jakarta Erlangga.

Mutmainnah. 2017. Pengaruh Kualitas Layanan dan Citra Perusahaan Terhadap Kepuasan dan Loyalitas Nasabah. Jurnal Manajemen dan Pemasaran Jasa. Vol. 10, No. 2, September 2017, 201-216

Naimi, Syedeh Safoura. The Impact of Brand Image on Customer Satisfaction and Loyalty Intention (Case Study: Consumer of Hygiene Products). International Journal of Engineering Innovation \& Research. Vol. 3, No. 1, 2014, 2277-5668

Neupane, Ramesh. 2015. The Effects of Brand Image on Customer Satisfaction and Loyalty Intention in Retail Supermarket Chain UK. International Journal of Social
Sciences and Management. Vol. 2, No. 1, 2015, 9-26

Puteri, AA dan Subagja, IK. 2017. Pengaruh Kualitas Layanan Dan Kualitas Produk Terhadap Kepuasan Pelanggan Pt. Rahman Wisata Mandiri Jakarta. Jurnal Manajemen Bisnis Krisnadwipayana. Vol. 5. No. 2. Hal. 1-14.

Rahayu. 2015. The Influence of Service Quality, Trust and Brand Image toward Customer Satisfaction and its Impact to Brand Loyalty. International Journal of Advanced Research. Vol. 3, No. 10, 2015, 1867-1873

Saleem, Hamad \& Raja, Naintara. 2014. The Impact of Service Quality on Customer Satisfaction, Customer Loyalty and Brand Image: Evidence from Hotel Industry of Pakistan. Middle-East Journal of Scientific Research. Vol.19, No. 5, 2014, 706-711

Setiawan, Heri \& Sayuti, Jalaluddin. 2017. Effects of Service Quality, Customer Trust and Corporate Image on Customer Satisfaction and Loyalty: An Assessment of Travel Agencies Customer in South Sumatra Indonesia. Journal of Business and Management. Vol. 19, No. 5, May 2017, 31-40

Sulistiyono, Agus. 2006. Manajemen Penyelenggaraan Hotel. Bandung: Alfabeta

Susanto, PH dan Subagja, IK. 2019. Pengaruh Kualitas Layanan, Kepuasan Nasabah Dan Citra Perusahaan Terhadap Loyalitas Nasabah Pt. BANK CENTRAL ASIA Tbk Kantor Cabang Pondok Gede Plaza. Jurnal Manajemen Bisnis Krisnadwipayana. Vol. 7. No. 1. Hal 69-84.

T. Khalil Bharwana, Mohsin Bahsir, Muhammad Mohsin. 2013. Impact 
of Service Quality on Customers Satisfaction: A Study from Service Sector especially Private Colleges of Faisalabad, Punjab, Pakistan. International Journal of Scientific and Research Publications. Vol 3, No. 5, Mei 2013, 1-7.

Tjiptono, Fandy. 2011. Pemasaran Jasa.

Malang: Bayu Media 